\title{
Lessons learned from a Ponzi game in Congo
}

\section{Jean-Anaclet Mampassi}

\author{
Marien Ngouabi University of Brazzaville and Lares
}

Corresponding author : mampassianaclet@gmail .com

Received: 31, March, 2021

Accepted: 08, April, 2021

Published: 15, April 2021

\begin{abstract}
To last, a Ponzi game requires a permanent flow of new lenders who get inserted into the system endlessly. In this paper, we show that, unlike Carlo Ponzi in Boston and Bindo Bolembé in Kinshasa (DRC), in the Salu Humberto Brada case in Congo Brazzaville, the debt of the borrower agent was also backed on real assets. This subdues the infinite horizon constraint of the scheme he implemented and shows how his Ponzi game could have gone on infinitely.
\end{abstract}

Keywords: Ponzi game, Congo.

JEL Classifications : O17 ; O55

\section{Introduction}

In the early 2000's, in the Republic of Congo (Brazzaville), a private operator known as Salu Humberto Brada (SHB) called for private savings by offering to the Congolese savers a 30\% interest rate on 45 days. The same proposals had already been expressed in the United States of America in the 1920's by Carlo Piètro Giovanni Guglielmo Tebaldo Ponzi. The activities of the financial branch of the SHB Group were roughly interrupted by the monetary authority a couple of years later, for legal motives, even if no default had been recorded before, while those of Carlo Ponzi turned out to be a huge financial fraud at the end of which thousands of American savers lost their bet.

This study points out the economic conditions thanks to which a Ponzi game can last forever. These conditions will allow us to appreciate the decision made by the monetary authority to put an end to the financial activities of the SHB group in the Republic of Congo-Brazzaville.

The economic literature on Ponzi game has focused on this particular kind of game. Some authors, such as Charles Kindleberger (1978), first analyzed Ponzi games simply as activities linked to financial scams. The Ponzi 'label' was later widely inserted into the economic theory, stripped of its fraudulent connotation. H. P. Minsky (1982) is certainly the first who must have included this notion into the financial theory. In the financial typology which he sets up, the author differentiates three types of financial structures:

- the one which resists unfailing, that is the structure of the covered agent (hedge finance unit), in which proceeds always exceed disbursements, what permits the agent not to get into debt ;

- that of the speculator agent (speculative finance unit), the balance of which depends on the interest rate in force in the financial market and
- That of the Ponzi agent (Ponzi finance unit), that is to say the structure the permanence of which is function only of the agent borrowing capacity.

This last financial structure describes 'a situation in which cash payments on debt are met by increasing the amount of the debt outstanding' (Minsky, 1982). Thus, the financial structure of the Ponzi agent is fundamentally unsound. Its expenses always exceed its entries. Therefore, to survive, that is to offset proceeds and disbursements, the Ponzi agent is obliged to increase his debt continuously. He gets into debt to cover his running costs and finances by the loan his survival, paving the way to the bankruptcy, which can only be postponed but not avoided. However, in Minsky's analysis, loans are guaranteed on real assets (assetsbacked lending), in other words the lenders and the borrowers expect, exante, that debts will be entirely repaid out of proceeds of real assets.

The neoclassical general equilibrium literature focused on a more fundamental aspect of the Ponzi game, that where loans are backed not by real assets, like in Minsky's study, but by future loans. Therefore, a Ponzi game describes a situation where a borrower reimburses forever his outstanding debts (interests and principal) by new loans (roll-over). So, the initial flow of resources, from lenders to the borrower, is not ultimately offset by a flow of equal present value in the opposite direction. That is why authors like O'Connell and Zeldes (1988) define a Ponzi game as 'a sequence of loans market transactions with positive present value to the borrower'.

The analysis of Ponzi game was then spread into the international debt field. Niheans (1985) and Bulow and Rogoff (1989), for example, showed that in the absence of sanctions others than exclusion (or restriction) from future borrowing, debtor countries are encouraged to default on any debt which would not constitute a rational Ponzi game, that is the one the refinancing of which would not be guaranteed. Therefore, lenders who assess the inherent risks of international lending have to be more concerned 
about willingness and abilities to further lending of other lenders, current or potentials, rather than only about insolvency risks peculiar to debtor countries.

Suppose that, unlike Carlo Ponzi, SHB was not guided by true desires of financial swindle (absence of asymmetric information), would the activities of his financial branch have been able to continue? To answer this question, we first present two cases of financial swindle linked to Ponzi game, then we focus on the specific case of SHB.

\section{Some cases of pyramid schemes}

\subsection{The historical case: Carlo Ponzi in Boston}

The Ponzi scheme is a fraud which was repeatedly implemented as well before as after CarloPonzi, an Italian immigrant in the United States, gives it his name in the 1920 's. Ponzi was a swindler who set up a financial institution based on savings, then invited American people to deposit their savings by offering a generous interest rate. Ponzi promised to 'double their money' in 90 days by pouring them a $50 \%$ interest rate on deposits in 45 days, while a banking account yield was only $5 \%$. In space of eight months, Ponzi managed to amass about 15 million US dollars on behalf of 40000 American savers o fNew England. Throughout his activities, he claimed to his credulous "clients" tha the was taking advantage of arbitrage opportunities in the American exchange market, thanks to operations of purchase-sale of international postal coupons. In fact, Ponzi was operating a financial chain letter, using funds from new investors to pay off earlier investors. Therefore, he was remunerated very widely on former deposits.

The system had worked until new deposits were not anymore enough to cover interests due on the earlier ones. He was arrested in Boston by the federal agents in August, 1920 and sentenced to three years and a half in prison. The inquiry revealed that Ponzi bought postal coupons only for 30 dollars and the debt due to the savers amounted to 2.5 million dollars, while at the time of his confinement he had only 60 dollars on him.

\subsection{Bindo in the former Zaïre}

In the former Zaïre (current Democratic Republic of Congo), the pioneer of Ponzi games was Michel BindoBolembé who, in Kinshasa in the early 1990's (marked by political turmoil and social riots and lootings), launched what was well-known as "Bindomania". The Bindo-promotion S.p.r.l. agency which he setup offered to the Congolese savers a $800 \%$ interest rate applied at the end of 45 days (the annual inflation rate was up to $1000 \%$ ). This perspective of earnings triggered a true frenzy on behalf of the Congolese savers who stormed the Bindo-promotion counters. Very fastly, when rumors and official media had justified the activities of this providential promoter, a messianic vocabulary was dedicated to him: «the founder of the social stability», "Bindo the Moses", "the doctor of poverty" or, bluntly, "the new messiah". In March, 1991, on the national radio-television, Bindo proclaimed : «Entrust me your thin savings and I make millionaires of you at the end of 45 working days».

However, Bindo was victim of his own success. His lavish personal expenses and the corruption of the collectors agents in the counters who carried out premature repayments against bribes or tampered with accounting documents, brought about the collapse of the pyramid. In May 1991, all Bindo agencies had to close. Wanted by students, journalists, dealers, and soldiers who threatened to slaughter him, Bindo had to vanish in Kinshasa. He was arrested by the police in June 1991 and served a couple of years in the central prison of Makala (Kinshasa). When the truth was at last revealed, it was always with the same religious vocabulary Bindo was reviled: he was then treated as the Antichrist, the enemy of God. Like Carlo Ponzi's activities, Bindo promotion turned out to be a huge scam.

\subsection{The specific case of SHB in the Republic of Congo}

In the Republic of Congo, some promoters tried to set up a Ponzi game in a more or less underground way. But the most interesting case from the point of view of the economic analysis is that of Salu Humberto Brada (SHB). SHB started his financial activities since 2000. He assured not to be a financial institution, but a simple commercial company calling for private savings to finance his activities of import-export and building housings. The promoter asserted injecting the sums gathered in commercial circuit through importation of goods (beans, cement, oil, etc. ) from Cameroon, South Africa, Namibia, Benin and Angola with expectation of a $100 \%$ gain, in 20 days. The savers, qualified as partners of the group, were not considered to be clients of a banking institution, but simple lenders financing investments of the commercial branch of the SHB group.

SHB borrowed money from the public to whom he reimbursed in a fixed term of 45 days with a $30 \%$ interest rate. Attracted by perspectives of earnings under certainty, thanks to the media covering which did not hesitate, as with Bindo in Kinshasa, to assimilate the promoter as a "rescuer", a lot of account owners of the micro-finance institutions and those of the traditional banking system had to re-affect their slightly-remunerated savings towards the financial branch of the SHB group. The leading Congolese mutual credit and savings institution, known as Mucodec, for example, had seen the growth trend of its deposits lowering to more than $50 \%$, in space of six months.

Concerned about this huge success which dangerously threatened the survival of the banking system in Congo, the Central African Monetary Committee (known as COBAC), seized by the national direction of the Central Bank of the Central African States (known as BEAC), demanded and got from the Congolese Ministry of Justice, in March, 2002, the immediate shutting down of SHB financial activities for "violation of a monopoly reserved to the only banking institutions". In June, 2002, the BEAC governor froze all SHB assets in the local banks. Since then, the ad hoc committee charged to supervise SHB financial wing liquidation has not been so far able to fully repay thousands of depositors, in spite of releasing in its benefit, by early July, 2002, every SHB banking accounts.

\section{3: The rationale behind the game and the attenuation of the infinite horizon constraint}

The Ponzi game is a pyramid scheme which requires few persons at first and a multitude at arrival. It is sometimes called "cavalry" or "the plane" because of the fact that the promoter often ends up flying off ,leaving his pilot's place to another one (often the lender of last resort). Contrary to random games, the Ponzi game is exclusively based on the credulity of the subscribers (the depositors) since it is not founded on chance but on certainty: the insurance that sums invested will be entirely paid off in a term and with an interest rate known beforehand.

So, why investing in agriculture, in trade or in quite other activity where, in the best of cases, profit margins do not exceed 20 $\%$, when it is easier to cross one's arms and wait that one's savings make profits at a term known beforehand? 
The development of a Ponzi system lays on an snowball effect fed by a herd behaviour of lenders. The start-up capital is not so massive, but it leans on the confidence of a small group of players who will be joined progressively by a more and more important number, among others thanks to the rumour which grows from the first repayment. So, not only arrive lots of new players, reassured by the previous ones who have just performed earnings, but these last ones are induced to delay earnings continuously until the day "the wagon of apples" collapses and the Ponzi agent, cornered, suspends payments. But why is he forced to suspend payments? Cannot the game continue infinitely?

\section{Three key points ought to be mentioned at the end of the SHB financial activities:}

When its assets were frozen by the monetary authority, its banking accounts were endowed with only two (02) billion CFA francs, for a total debt estimated to about 30 billion CFA francs (about 25 billion in Brazzaville and 5 billion in Pointe Noire). These sums were owed to about twenty thousands (20000) savers ;

A share of the collected funds served to finance commercial and property investments of the SHB group.

No default was recorded up to the shutting down of its activity by the monetary authority.

On the one hand, in the light of this theoretical framework, one can understand why no defaut had been recorded in the SHB financial activities. As his reputation was made on the (informal) financial market, there were new lenders who got integrated into the game, so assuring its permanence. In this respect, it is necessary to mention that the group was far from having exhausted the reservoir of potential lenders who could have been attracted by earnings which offer its financial activities.

On the other hand, the lowness of the SHB banking assets with regard to sums to be reimbursed to the lenders is not surprising since, to make a Ponzi game running, the borrower agent does not need to have all funds gathered. He only has to make sure, in each period, that he has the necessary sums for daily withdrawal by earlier lenders.

Moreover, the game implemented by SHB was not an outright financial scam since a share of loans asked for by SHB group served to finance activities of its commercial (speculation on foodstuff), real property (building social accommodation) and semi-industrial (unit of treatment of fish, etc. ) branches. Even if it is not easy to assess the value of real assets so collected, their very existence leads us to move away the SHB case from Charles (Carlo) Ponzi or Bindo Bolembé's one. The SHB scheme was an asset-backed Ponzi game. In other words, loans were, at least partly, guaranteed on real assets. Thus, in case new loans were not anymore enough to cover daily withdrawal, the incomes raised from tapping (or selling) those real assets would have allowed him to fill the gap up.

The productive use of funds collected in a Ponzi game leads us to the integration issue between microfinance and micro-firm and to that of the micro-financing of development. The development of microfinance activities in African countries, mainly in those of the CFA franc area, is not foreign to the financial repression which is practised in it. The creditor real interest rates are at a ridiculous low level against prohibitory debtor rates. One of the responses brought by the private operators in search of domestic funds was to offer higher creditor interest rates to savers so as to collect necessary funds needed to launch highly profitable commercial or property speculations.

Of course, the financial scheme implemented by SHB was really compulsive (30\% within 45 days). However, it may be possible to conceive a financial scheme offering to savers a moderate creditor interest rate (from 12 to $15 \%$ ) applied in 90 days. The collected funds would not serve to reproduce a genuine Ponzi game, but to finance highly profitable commercial or property investments. This aspect seems to have escaped to the central African monetary authority, more anxious about the resilience of the traditional banking system.

\section{4: Conditions of the perpetuation of a Ponzi game}

Ruling out irrationality or asymmetric information (mainly unsaid desires of financial scams from Ponzi agent), a Ponzi game can work on infinitely on the sole condition that there are permanently new lenders who are inserted into the system. As long as this condition is fulfilled, financial markets will survive from speculative bubbles. Moreover, the pension system by allotment, in force in France and in Congo, which some authors assimilate to the Ponzi game (because, it always presupposes an indeterminate growth) could outlast.

In accordance with this framework, the 1980's debt crisis set off because the international lenders were not any more willing to keep lending to the main debtor countries like Mexico and Brazil. If banks had normally pursued their lending operations, debtor countries would have, thanks to new loans, kept repaying their lenders. But, among others, the free rider problem had broken the game and thrown the highly indebted countries into crisis.

Some secondary clauses derive from the necessity of an infinite number of lenders in a Ponzi game. First, as the population is in each period finite, the perpetuation of Ponzi game requires perpetual birth of new lenders into the economy, these ones offsetting beyond what is necessary the unavoidable deceases.

Second, the game would be unsettled in case lenders would act in different ways. So, not only the number of agents must be infinite, but their lending behaviour must also reproduce infinitely. In other words, these lenders must be both numerically and behaviorally infinite.

Third, with an infinite number of lenders, the borrower agent can be able of reimbursing every generation of lenders by borrowing from the following generation. Thus, the logic of a Ponzi game should be analyzed properly only as part of a dynamic world with overlapping generations (OG), rather than in a ArrowDebreu world.

In the OG framework, individual live finite lifetimes, but the economy goes on forever. Hence, the OG model is doubly infinite: there are an infinite number of individuals and an infinite number of dated commodities. Even if the present generation cannot trade directly with future generations, they are not isolated or merely successive. They overlap. Because of this, the decisions of current generations potentially affect through forward induction the actions of all future generations, and the anticipated decisions of future generations affect through backward induction the actions of current generation.

\section{5: Conclusion}

The Ponzi game is a particular scheme which generates a permanent debt. It does not have an endpoint and ought to go on 
forever. By shutting down the SHB financial activities, the monetary authority should have expected that the banking assets of this group at that time would not be enough to repay all lenders. Since the game works only when there are new lenders who flow continuously, repaying them would have inevitably required the intervention of a lender of last resort, that is to say the monetary authority itself.

The monetary authority would have better pointed out financial arguments (collapse risks of a pyramidal scheme) to close down the SHB financial branch rather than leaning exclusively on legal argument (the violation of a banking monopoly). This argument was misunderstood by the lenders since the SHB group had been running its activities for two years without being worried.

If the monetary authority put an end to the SHB financial activities, maybe because it did not believe that the group would have satisfied strong conditions linked to the perpetuation of a Ponzi game and the secondary clauses which derive from it.

However, the scheme set up by SHB group was not the archetype of a financial scam implemented by Carlo Ponzi in the 1920 's since, at least a share of the collected sums served to amass and tap real assets. The repayment of lenders was not any more backed on the sole flow of new deposits, but also on net earnings expected from these real assets. This perspective attenuates the infinite horizon constraint. Thus, the SHB financial structure gets closer to that of Minsky's Ponzi agent (fragile financial unit, but boosted by real assets). This seems to have escaped to the local monetary authority.

Another more fundamental motive could have led the monetary authority to opt for the closing down of the SHB financial activities. The huge success of its financial activities and the realization of the infinite number of lenders would have seriously jeopardized the local banking system, which had already seen its turnover going down dangerously. In the long run, indeed, it would not have been impossible that creditor agents withdraw their slightly-remunerated assets from banks to SHB. The collapse of the local banking system would have been unavoidable.

\section{References}

[1] Bulow, J and Rogoff, K. (1989), Sovereign Debt: Is to Forgive to Forget? American Economic Review, vol.79, 43-50.

[2] Crettez, B et al. (2000), Jusqu'où l'Etat peut-il s'endetter. Une approche par les génératons imbriquées d'agents.
Document de travail du CREQAM, EHESS, universités d'Aix-Marseille II et III, avril.

[3] Delahaye, J-P. (2009), Escroquérie ou jeu risqué? Pour la science, ${ }^{\circ} 385$, nov.

[4] Frankel, T. (2012). The Ponzi Scheme Puzzle : A History and Analysis of Con Artists and Victims. USA: Oxford University Press. Frey, M.J. (1995). Money, Interest and Banking in Economic Development, The John Hopkins University Press, Baltimore, USA.

[5] Gondola, Ch. D. (1997), Jeux d'argent, jeux de vilains : rien ne va plus au Zaïre. Politique Africaine, $n^{\circ} 65$, mars, 96-111.

[6] Jarvis, CH. (2000), Grandeur et décadence des pyramides financières en Albanie. Finances et Développement, mars, 46-49.

[7] Kindleberger, C.P. (1978), Manias, Panics and Crashes : A History of Financial Crises. Basic Books, New York, USA.

[8] Madhavan, S. and Barrass, R.(2011). Unsustainable Development: Could it be a Ponzi Scheme? Journals openedition, vol. $4, n^{\circ} 1$

[9] McKinnon, R.I. (1981), Financial Repression and the Liberalization Problem Within Less-Developped Countries, in The World Economic Order. Past and Prospects, Sven Grassman and Erik Lundberg (eds), Macmillan, London, UK, 365-86.

[10] Minsky, H.P (1982),Can 'It' Happen Again? Essays on Instability and Finance, Armonk, M.E. Sharpe, Inc, New York, USA.

[11] Moreau, R. (2010), L'escroquérie à la Ponzi et autres arnaques financières. Insurance and Risk Management, vol.77, n³-4, Oct. 2009-Janv.2010.

[12] Nash, J.R. (1995), Bloodletters and Badmen, A Narrative Encyclopedia of American Criminals from the Pilgrims to the Present, M. Evans, New York, USA.

[13] O'Connell, S.A. and Zeldes, S.P. (1988), Rationale Ponzi Games. International Economic Review, vol.29, 431-50.

[14] O’Connell, S.A. and Zeldes, S.P (1992), Ponzi Games. The New Palgrave Dictionary of Money and Finance, vol. 3, Macmillan, London, UK, 147-49.

[15] Rand, S and Jaeger, A. (1996), Aging Populations and Public Pension Scheme. International Monetary Fund Occasional Papers, $n^{\circ} 147$.

[16] Zuckoff, M.(2005). Ponzi's Scheme: The True Story of a Financial Legend. New York: Random House 